\title{
GÜNLÜKLERDE YANSITICI DÜŞÜNCELER
}

\author{
Araştırma Makalesi / Research Article
}

\begin{tabular}{l|l} 
Sağlam, M. H. (2020). Günlüklerde Yansıtıc1 Düşünceler & Geliş Tarihi: 05.07.2020 \\
Nevşehir Hacl Bektaş Veli Üniversitesi SBE Dergisi, & Kabul Tarihi: 03.12.2020 \\
10(2), 591-607. & E-ISSN: 2149-3871 \\
DOI: 10.30783/nevsosbilen.764562 &
\end{tabular}

Dr. Öğr. Üyesi M. Halil Sağlam

Siirt Üniversitesi, Eğitim Fakültesi, Türkçe ve Sosyal Bililer Eğitimi Bölümü

mhalil.saglam@gmail.com.tr

ORCID No: 0000-0001-7557-7021

\begin{abstract}
ÖZ
Yansıtıcı düşünce temelde eğitim bilimleriyle ilgili bir kavramdır ve bir öğretim tekniği olarak kullanılmaktadır. Bu teknikle kişilerin yaptıklarını değerlendirmeleri, değerlendirmelerinden ders çıkarmaları, sorumluluk üstlenmeleri ve öz eleştiri yapmaları istenmektedir. Yazar ve şairler, bu tekniği günlük ve anı gibi hikâye edici metinlerde sıklıkla kullanmaktadırlar. Dolayısıyla yansıtıcı düşüncenin edebiyat bilimiyle ilişkisi bulunmaktadır. Bu çalışmada günlüklerde yer alan yansıtıcı düşünceler tespit edilmektedir. Yazarlar, yansıtıcı düşüncelerle geçmişlerini sorgulamakta, pişmanlıklarını itiraf etmekte, hayatlarıyla ilgili yeni çıkarımlarda bulunmaktadır. Günlükler bu yönüyle yazarların biyografilerinde yer almayan önemli bilgileri içermektedir. Bu çalışmanın amacı, sanatçıların hayat tecrübelerinden yararlanmak ve onları farklı yönleriyle tanımaktır. Türk edebiyatında günlük türünde kaleme alınmış sınırlı sayıda eser bulunmaktadır. Eleştirmen yönleri ortak olan Nurullah Ataç, Ahmet Hamdi Tanpınar, Oktay Akbal ve Cemil Meriç'in günlükleri bunlar arasında önemli bir yere sahiptir. Yazarlar, günlüklerinde samimi duygularla geçmişlerini sorgulamakta, öz eleştiri yapmakta ve pişmanlıklarını dile getirmektedirler. Çalışmadan çıkan ortak sonuca göre yazarlar, geçmişlerini sorguladıkça ve öz eleştiri yaptıkça yeni ve doğru bilgilere ulaşmaktadırlar. Günlüklerdeki yansıtıcı düşünceler, ayrıca yazarları farklı yönleriyle tanıma firsatı vermektedir.
\end{abstract}

Anahtar Kelimeler: Günlük. Yansıtıcı Düşünce. Ataç. Tanpınar. Meriç. Akbal.

\section{REFLECTIVE THOUGHTS IN DIARIES}

\section{ABSTRACT}

Reflective thinking is basically a concept related to educational sciences and is used as a teaching technique. With this technique, it is ensured that people evaluate what they do, learn from their evaluations, take responsibility and make self-criticism. Authors and poets often use this technique in narrative texts such as dairly and reminiscence. Therefore, reflective thinking has a relationship with the science of literature. In this study, reflective thoughts in the diaries are determined. The authors question their past with reflective thoughts, confess their regrets and make new inferences about their lives. Diaries in this respect contain important information not included in the biographies of the authors. The purpose of this study is to take advantage of the life experiences of the artists and to know them from different aspects. In Turkish literature, there are a limited number of works written in daily genre. The diaries of Nurullah Ataç, Ahmet Hamdi Tanpınar, Oktay Akbal and Cemil Meriç, whose critic aspects are common, have an important place among them. The authors question their past in their diaries with sincere feelings, make self-criticism and express their regrets. According to the common result of the study, the authors reach new and accurate information as they question their past and make self-criticism. Reflective thoughts in the diaries also give the opportunity to get to know the authors from different aspects.

Keywords: Daily. Reflective thinking, Ataç. Tanpınar. Meriç. Akbal.

\section{GíRiş}

\subsection{Düşünme Kavramı Üzerine}

Düşünme insana özgü bir yetidir. İnsan, düşünme yetisiyle karşılaştırma, ayırma ve birleştirme yapar; bağlantıları ve biçimleri kavrar. Türkçe Sözlük’te düşünmeyle ilgili şu ifadeler 
geçer: "Aklından geçirmek, göz önüne getirmek; bir sonuca varmak amaclyla bilgileri incelemek, karşılaş̧tırmak ve aradaki ilgilerden yararlanarak düşünce üretmek, zihinsel yetiler oluşturmak, muhakeme etmek; zihniyle arayıp bulmak; bir şeye karşı ilgili ve titiz davranmak; akıl etmek, ne olabileceğini önceden kestirmek; tasarlamak; tasalanmak, kaygllanmak; farz etmek(tir)" (Akalın, 2011: 743). Farklı bir tanımlamaya göre ise düşünme, zihinsel bir üretimde bulunma ve zihinsel katma değer üretme çabasıdır (Başar, 2013: 3). Kişinin içinde bulunduğu durumu anlaması için yaptığı amaca yönelik, aktif ve organize zihinsel süreç de düşünme olarak tanımlanmaktadır (Kurnaz, 2013: 2). Bu tanımlamalardan çıkan ortak sonuca göre düşünme, bilinenleri kullanarak bilinmeyeni üretmek; üretilen bilgilerle de bilgiyi sorgulama ve kullanma çabasıdır.

Felsefede düşünme, aklın bağımsız ve kendine has fiilidir. Bu yönüyle duyum, tasarım ve izlenimden ayrılır. Düşünme, gerçek nesnelere yönelirse somut düşünme; ideal nesnelere yönelirse soyut düşünme gerçekleşmiş olur (Akarsu, 2016: 64). Düşünme, kişinin öğrenme süreci içinde kazandığı kavramlar ve kullandığı imgelerle gerçekleşir. Felsefecilerin düşünmeyle ilgili farklı görüşleri bulunmaktadır. Batılı filozoflar arasında felsefe denlince ilk aklan gelen şey düşünsel bir monologdur. Sokrates, bu genel yargıyı değiştirir. Sokrates, insan doğasının bilgisine ancak diyalektik düşünme modeliyle ulaş1labileceğini savunur (Günay, 2010: 14). Platon, düşünme kuramında varlıkları duyulanlar ve düşünülenler olmak üzere iki gruba ayırır. İnsan, düşünülen varlıkları araştırarak bilgiye ulaşır. Düşünme, bir anlamda insanın kendi içinde var olanı dışa aktarmasıdır (Platon, 1942: 28). Eleştirel aklın öncüsü Aristoteles ise insanın düşünme sayesinde bitki ve hayvan ruhlarından daha yüksek bir değere sahip olduğunu savunur (Gökberk, 1993: 87). İnsan, aklını kullanarak mutlu olur ve varlığının farkına varır. Akıl, kendinde durur ve ereği kendindedir. Kendini var edeni gerçekleştirir. Düşünme bu akıl ereğinin bilincine sahip olmak ve irade göstermektir (Hegel, 2011: 36). Filozof Descartes, düşünmeyi insan ruhunun en önemli vasfi olarak görmektedir. Ruh bir cevherdir ve varlığını ancak düşünmeyle gerçekleştirir. Ruh, anne karnından itibaren düşünmeye başlar (Özden, 1996: 172). Descartes'ın düşünce felsefesine göre gerçek bir düşünce eylemi için olaylara şüpheyle bakmak gerekmektedir. Çünkü olgu ve nesnelere şüpheyle bakılması insanda araştırma duygusunu geliştirir. Araştırmayla birlikte analiz etme, kavrama ve düşünme gibi zihinsel eylemler gerçekleşmiş olur. Shopenhauer, düşünme eyleminin gerçekleşmesi için öğrenmeyi şart koşar. Çünkü insan bilmediği bir şey hakkında düşünme eylemini gerçekleştiremez (Aydoğan, 2012: 27). Bilgisizlik merak duygusunu harekete getirir. Merakla araştırılan bilgi, analiz edildikçe düşünme eylemi aktif hale gelmiş olur. Immanuel Kant, düşünme eylemini kavramcılık olarak açıklar. "Kavramcılık doğulunun, hem bilim alanında hem de günlük hayatta en çok başvurduğu düşünme tarzıdır. Doğulu için bilim ve felsefe ezberlenen, yüklenmesi gereken içi boş kavramlarla yüklüdür" (Heımsoeth, 2014: 10). Doğulu gençlerin üniversitelerde bilim üretmediklerini eleştiren Kant, buralarda bilginin analiz edilmeden sadece ezberlendiğini iddia eder. Eğitim bilimleri uzmanı John Dewey'e göre düşünme: "Doğrudan olmadan, gözlem, kanıt ve belge destekleme yoluyla inanma veya inanmama anlamına gelir, fikrin temeli de budur" (1933: 6). Doğulu filozofların da düşünme ile ilgili farklı görüşleri vardır. Aristo’yu İslam dünyasına tanıtan İbn Rüşd, düşünme eylemini akılla ilişkilendirerek açıklar. Aklın dört aşaması vardır. Birinci aşama hiçbir bilgiye sahip olmayan Heyulani akıldır. Bu akla, meleke akıl da denir. Aklın bu aşamasında bilgi ve düşünce üretilebilmektedir. Aklın ikinci aşaması mükteseb akıldır. Bu akıl aşamasında bilgi ve idrak harekete geçer. Faal akıl kavramıyla açıklanan üçüncü aşamada ise sürekli devam eden bir düşünme eylemi gerçekleşir. Aklın dördüncü aşaması ise olgunluktur. Bu aşamada akıl, aktif bir zihinsel faaliyet içerisindedir. İnsan, varlık âlemini bu zihinsel faaliyetle idrak eder ve sorgular (Aruç, 2007: 79-80). Bilim insanı İbn-i Sina düşünmeyi ruhla ilişkilendirerek açıklar. İnsan, varlık bilincine ancak ruhu sayesinde varır. Düşünme olmadan da ruhun bu bilince ulaşması mümkün değildir (Özden, 1996: 109). İbn-i Sina'ya göre ancak taklitten arınmış bir düşünce ruhu harekete geçirir. Düşünmek, bilgiyi olduğu gibi transfer etmek değil, aramak, bulmak ve yorumlamaktır. Düşünce eylemi canlı oldukça ruh kemâle erer. İnsanın mutluluğu da ruhu olgunlaştıran düşünce eylemiyle gerçekleşir (Özden, 1996: 111, 112).

Düşüncenin felsefe biliminin dışında eğitim bilimlerine bakan yönleri de bulunmaktadır. Eğitim bilimlerinde temel amaç bireye sistemli düşüme ve sorgulama yeteneğini kazandırmaktır. Farklı öğretim teknikleriyle sağlanan bu kazanımlar bireyin zihinsel işlem ve süreçlerini harekete 
geçirmekte, problem çözme, karar verme ve kavramlaştırma becerilerini geliştirmektedir (Güneş, 2012: 128). Eğitim bilimlerinde farklı türlerde düşünme teknikleri bulunmaktadır. Bireyin etkili ve kalıcı öğrenmesini hedefleyen bu düşünme tekniklerinden bazıları şunlardır: Sistematik düşünme, analojik düşünme, analitik düşünme, yaratıcı düşünme, üst düzey düşünme, yansitıcı düşünme, eleş̧tirel düşünme, tümdengelim düşünme, empatik düşünme, pragmatist düşünme ve öyküsel düşünme. Düşünme türlerinin her biri eğitim bilimlerinin temel bileşenleri arasında sayılır. Bireyin bilgiyi işlemesi, zihinsel şemalarını gözden geçirmesi ve düzenlemesi için düşünme gereklidir (Güneş, 2012: 136). Düşünme türlerinin sistematik bir şekilde uygulanması bireylerin bilgiyi gerçekleştirme, sorun çözme ve fikir üretme becerilerini geliştirir. Yansitıcı düşünme, bu türler arasında en etkili düşünme yöntemlerinden biridir.

\subsection{Yansıtıcı Düşünme Kavramı Üzerine}

Yansitıcı düşünmenin kuramcısı Amerikalı filozof John Dewey'dir. Dewey, yansitıcı düşünme tekniğini yansıtma kavramından yararlanarak geliştirmiştir. Kavram, Latince geriye kıvrılma, bükme, dönme anlamına gelen "reflectere" kökünden gelmektedir (Bakioğlu ve Dalgıç, 2014: 14). Kavramın isim türündeki anlamı: "ış̧ı, ses, görüntü vb.ni geri göndermek, yansımasını sağlamak amacıyla kullanılan araç, yansitaç, reflektör"; sıfat türündeki anlamı ise "yansıtma işini yapan" demektir (RTL 1). Eğitim bilimleri alanında yansıtıcı düşünmeyle ilgili farklı tanımlamalar yapılmaktadır. John Dewey'in tanımlamasına göre yansıtıcı düşünme, amaçlanan sonuçları desteklemek için bilgi yapısını aktif, tutarlı ve dikkatli biçimde tasarlayan düşünme çeşididir (1933: 9). Dewey, yansitıcı düşünmeyi geçmiş tecrübelerden yararlanılarak elde edilen bir bilgi ve bu bilgilerin hedeflediği zihinsel verimlilik olarak kabul eder. Bireyin geçmiş tecrübelerinden yararlanabilmesi ve zihinsel verimliliğini arttırabilmesi için açık fikirlilik, tam isteklik ve sorumluluk gibi üç temel beceriye sahip olması gerekir. Osterman ve Kottkam yansıtıcı düşünceyi analitik bakış açısıyla ilişkilendirerek şu şekilde tanımlarlar: "Kişinin gelecekte daha iyi eylemlerde bulunması için seçim ve karar vermesini geliştirmek amaçll, dışardan bir gözlemci gibi, eylemlerinde, farkındalık ve analitik bakış açısı uygulama döngüsü” (1993: 183). Yansitıcı düşünme, Ünsal Ünver'in tanımlamasına göre ise "bireyin öğretme veya öğrenme yöntemi ve seviyesine ilişkin olumlu veya olumsuz durumları meydana çıkarmaya ve problemleri çözmeye yönelik düşünme süreci(dir)" (2003: 5). Yansıtıcı düşünme farklı bir bakış açısıyla, öğretimde yapılandırmacılık temelinde olan başkalarına önem vermeyi ön plana çıkaran sorgulayıcı bir yaklaşımla problem çözme faaliyetlerinin bütünüdür (Ergen, 2014: 284). Firdevs Güneş'in tespitlerine göre ise: "Yansitıcı düşünme, çeşitli hipotezler oluşturma, bunlar üzerinde çalışma ve test etme, tümevarım yoluyla veri toplama ve tümdengelim yoluyla sonuçlara ulaşmayl içeren bir düşünme türüdür” (2012: 133). Yansitıc1 düşünen birey, akılc1 ve sistematik sorgulama becerisine sahip olur. Akılcı ve sistematik düşünme de bireyin karar verme, fikir üretme ve öz eleştiri yapma becerisini geliştirir. Bireyin geçmişini sorgulaması ve yanlışlarının farkına varması eleştirel alanda yapılan bir yansıtıcı düşünmedir. Bu alanda yapılan yansıtma, bireyin iyi olan beklentilerinin keşfedilmesini sağlar (Ünver, 2003: 12). Yansitıcı düşünme temelde üç aşamada gerçekleşir. İlk aşamada bireyin çelişkili duygular yaşamasına sebep olan problem fark edilir. Bu aşamada zihinsel bir duraksama ve karmaşa yaşanır. İkinci aşamada problemin sınırları belirlenir. Üçüncü aşamada ise problemi çözmeye yönelik araştırma ve sorgulama yapılır. Yansıtma süreci ise "tekrar çağrıştırma", "akla uydurma" ve "yansıtma" olmak üzere üç düzeyden oluşmaktadır. "Tekrar çağırma düzeyinde" kişi sadece yaşadığ 1 deneyimi açıklayarak tecrübe ettiği şeyi betimler. "Akla uydurma düzeyinde" kişi deneyimleri arasında ilişki kurar, durumların sebep sonuçlarını açıklar ve deneyimlerini geneller. "Yansıtma düzeyinde" ise deneyimlerin değişim ve geleceği iyileştirme amaçlı ele alınır ve farklı bakış açılarına göre analiz edilir (Lee, 2005).

Yansıtıcı düşünmede kişi bilişsel alanda kendisini fark etmiş olur. Bir alanda öğrendiği bilgiyi başka alana transfer eder ve böylece yeni bilgiyi gerçekleştirmiş olur. Bu düşünme tekniğinde kişinin kendi yaşantısından veya başkalarının yaşantısından da ders çıkarması mümkündür.

Yansıtıcı düşünmeyi geliştirici farklı nitelikte teknikler vardır. "Mikro öğretim”, "öğrenme denetimleri", "görüşme-mülakat", "eylem araştırması", "mentorlük, meslektaş gözlemi", "vaka incelemesi", "rol model", "doküman içerik analizi”, "yazma ve not alma", "günlük tutma", "metafor kullanma", "otobiyografiler", "güçlü ve zayıf yönlerin analizi” bu tekniklerden bazılarıdır (Bakioğlu 
ve Dalgıç, 2014: 101). Günlük tutmak bir öğretim tekniği olmakla birlikte temelde edebiyatla ilişkili bir yazı türüdür. Dünya edebiyatında yazarların ve şairlerin yansıtıcı düşünceleri üzerine kurgulanmış çok sayıda günlük bulunmaktadır. Yazarlar, günlüklerinde pişmanlıklarını, kırgınlıklarını, yalnızlıklarını ve değişen iç dünyalarını anlatmaktadırlar. Sanatçıların yansıtıcı düşünceleri günlüklerinde estetik yargıya dönüştürmektedir.

\subsection{Günlük Türü Üzerine}

Günlükler üzerlerinde yazma tarihlerinin bulunduğu anı yazılarıdır. Suut Kemal Yetkin'in ifadesiyle yazarların kendi kendileriyle alçak sesle konuşmalarıdır (1962: 432). İç konuşma bir anlamda "insan bilincinin dış dünyayı nasıl idrak ettiğini" yansıtır (Bourneur and Quellet, 1989: 181). Günlük türü, Türk edebiyatına Batı edebiyatından gelmiştir. Türün Batı edebiyatındaki karşılı̆̆ 1 daily ve jurnaldir. Günlük türünü Osmanlılarda resmî evrak olarak kullanılan ruznamelerle karıştırmamak gerekir. Osmanlı literatüründe müneccimlerin yıllık takvimlerinden günlük hadiselerin anlatıldığ 1 tarihlere uzanan geniș bir alanda ortaya çıkan değișik türden eserlerle bürokraside günlük gelir ve giderlerin kaydedildiği defterlere ruzname denilmiştir (Sarıcaoğlu, 2008: 278-281). Ruznameler, kimin adına hazırlandığı belli olmayan birer arşiv belgeleridir. Bu tür belgeler Osmanlılar döneminde padişahlarla sadrazamlar arasında gizliliği olan yazışmaları yöneten sır kâtipleri tarafından arşivlenmekteydi. Günlük türünün en önemli özelliği olayların ve etkilerinin sıcağ1 sıcağına yazıya geçirilmesidir (Mert, 2015: 26). Günlüklerin bir diğer özelliği de birinci şahsa dayalı olmaları ve öznel yargılar içermeleridir.

Türk edebiyatında günlük türünde yayımlanan ilk eser Direktör Âli Bey'in "Seyahat Jurnali'dir" (1897). Âli Bey, Batıdaki roman, tiyatro, dram, komedya gibi edebî türlerin o devirde kendi adlarıyla aktarılması geleneğine uyarak günlüklerini "Journal" adı altında yayımlamıştır. "Seyahat Jurnali" Âli Bey'in İstanbul'dan Hindistan'a uzanan gemi yolculuğunda tuttuğu günlüklerden oluşmaktadır. "Seyahat Jurnali" Türk edebiyatında günlük türünün ilk örnekleri arasındadır. Hikâyeciliğiyle tanınan Ömer Seyfettin'in de Balkan Savaşlarının yaşandığı dönemde (1912) tuttuğu günlükleri bulunmaktadır. Günlükler, yazarın ölümünden sonra Niyazi Ahmet Banoğlu tarafından bulunup "Hayat" mecmuasının 12 Ocak 1967 tarihli 3. sayısı ile 23 Mart 1967 tarihli 13. sayıları arasında tefrika edilmiștir (Yıldırım, 2011: 7). Günlükler savaş yıllarında Anadolu halkının yaşadığı trajediyi açıkça yansıtmaktadır. Cumhuriyet öncesi dönemde kaleme alınan bir başka günlük örneği de tarihçi Ahmet Refik'e aittir. Refik Bey, 1918 yılında Trabzon, Erzurum, Kars, Ardahan ve Batum'a yaptığı yolculuk sırasında tuttuğu günlüklerini "Kafkasya Yolculuğu” adı altında yayımlamıştır. Bu dönemde kaleme alınmış Şair Nigâr Hanım ve İbnülemin Mahmut Kemal'in günlüklerinin de göz ardı edilmemeleri gerekir.

Günlük türü, asıl olarak Cumhuriyet sonrası dönemde gelişmiştir. Dönemin yazar ve şairlerinin türle ilgili verdikleri örnekler türe karşı ilgiyi arttırmıştır. Fakat bu dönemde günlük türüyle ilgili kavram karmaşası yaşanmıştır. Salah Birsel, Türk edebiyatında günlük kavramını ilk kez (1949) kendisinin kullandığını iddia etmektedir (1978: 3). Suut Kemal Yetkin de bu konuda aynı görüştedir. Yetkin, bu konuda şu ifadeleri kullanır: "Her ne sebeple olursa olsun, artık bir edebiyat türü olarak günlük, son günlere kadar bizde yoktu. Bunun içindir ki Salah Birsel'in memleketimizde ilk örnek olan Günlük'ünü bir edebiyat olayı saymamız gerekir” (1962: 433). Falih Rifk1 Atay da günlük türünün öncüleri arasındadır. Fakat $o$, "Cumhuriyet" gazetesinde çıkan günlük yazıları için "Gündelik ve Gündem" sözcüklerini kullanmayı tercih etmiştir. Günlük türünün öncü isimlerinden Nurullah Ataç ise yazılarında günlük yerine günce sözcüğünü kullanmayı tercih eder. Melih Cevdet Anday'ın da tercihi aynıdır. Anday, anıları üzerine kurguladığı romanını "İsa'nın Güncesi” (1974) adı altında yayımlamıştır. Türk edebiyatında günlük yerine Fransızca jurnal sözcüğünü kullanan yazarlar da bulunmaktadır. Direktör Âli Bey'in dışında Cemil Meriç'in günlükleri ölümünden sonra "Jurnal I ve Jurnal II" adı altında yayımlanmıştır. Günlük türünün günümüzde en yaygın kullanımı isminden de anlaşıldı ğ üzere günlük şeklindedir.

Günlükler yazarların anlatım tekniklerine göre "içe dönük" ve "dışa dönük" olmak üzere iki gruba ayrılmaktadır. "İçe dönük" günlüklerde yazarlar başkalarıyla paylaşmadıkları dertlerini, pişmanlıklarını, geleceğe dair kaygılarını anlatırlar. Yetki'nin ifadesiyle "bu tür günlükler içe dönük yazarların âdeta içlerinden kopmuş yapraklardır. Bunlar şuurun alacakaranliğından, iç dünyanın derinliklerinden kopmuş hayaletler, parlttılar, ayaklanmalar, yatışmalarla doludur" (1962: 432). 
Türk edebiyatında Ahmet Hamdi Tanpınar ve Nurullah Ataç'ın; Fransız edebiyatında Stendhal'ın ve Andre Gide'in, Alman edebiyatında Franz Kafka'nın; Rus edebiyatında da Alexander Sergeyeviç Puşkin'in; İngiliz edebiyatında Samuel Pepys'in ve Katherıne Mansfield'in bu türde günlükleri bulunmaktadır. "Dışa dönük" günlüklerde ise sosyal konular, yaşanılan olaylar ve bu olayların yazar üzerindeki etkisi anlatılır (Özdemir, 1990: 133). Bu tür günlüklerde daha çok sanat, edebiyat, siyaset ve ekonomi gibi sosyal konular ele alınmaktadır. Türk edebiyatında Oktay Akbal, Salah Birsel ve Cemil Meriç; Fransa edebiyatında Alfred de Vigny ve Marie Bashkirtseff; Alman edebiyatında Ernst Junger ve Alfred Kantorowicz; İtalyan edebiyatında Cesare Zavattini ve Nicolo Barbaro; İngiliz edebiyatında James Boswell, Jonathan Swıft ve Land Augusta Gregory dışa dönük günlük yazarları arasinda sayılabilirler.

Günlükler bir de "edebiyat günlüğ̈̈” ve "özel günlük” ş̧eklinde ikiye ayrılmaktadır. İnsan ruhuna eğilen yazarların günlükleri "özel günlüklerdir. Fransızların "journal intime” adını verdikleri "özel günlükler”, kişilerin iç dünyalarını yansıtır. "Denilebilir ki bunlar yalnızlı̆̆a dönük kişilerin iç dökmeleridir. Bunlar içinde Amerikall yazar Henry Thoreau'nun (1817-1862) tam 39 defter tutan ve yaşamının 1837 ile 1861 yılları arasına sı kışan kesimini veren günlü̈̆̈̈ başı çeker” (Birsel, 1978: 7). Bunun dışında Henri Frederic Amiel'in, Stendhal'in, Alfred de Vingy'in ve ressam Eugene Delacoix'nin günlükleri de bu tür günlük arasında değerlendirebilir.

Edebiyat günlükleri ise şair ve yazarların kaleme aldıkları içlerinde edebî eleştirilerin yapıldığı günlüklerdir. Bu tür günlüklerde yazarlar mümkün olduğunca söz sanatlarından, farklı anlatım tekniklerinden ve düşünceyi geliştirme yollarından yararlanırlar. Türk edebiyatında Suut Kemal Yetkin, Nurullah Ataç, Oktay Akbal ve Salah Birsel; Fransız edebiyatına Stendhal, Charles Beaudelaire, Goncourt Kardeşler, Andre Gide; Alman edebiyatında Johann Wolfgang Goethe, Hans Corasa ve Franz Kafka; Amerikan edebiyatında Ralph Waldo Emerson ve Walt Whitman; İngiliz edebiyatında Samuel Pepys ve Virgina Woolf; İtalyan edebiyatında Cesare Pavese ve Nicalo Barbaro edebiyat günlüğü alanında eser veren önemli yazarlardır. Söz konusu bütün yazarlar, günlüklerinde tesiri altında kaldıkları olayları açıklamakla birlikte geçmişle ilgili pişmanlıklarını veya gelecekle ilgili kaygılarını dile getirmektedirler.

Günlüklerde yazarlar kendilerini değerlendirme ve öz eleştiri yapma firsatı bulurlar. "Yazarla hayat arasındaki beşerî ve estetik mesafenin anlaşılmasında günlük, önemli ipuçları verir. Kendi kendini tahlil ederken yazarm dikkati kendi benine yönelir. Olaylar ve insanlar hakkındaki dikkatlerini samimî bir şekilde kaydeder ve kendi konumunu da bu kayıtlar üzerinden tayin eder. Bir anlamda yazar ve günlük baş başadır" (Koç, 2014: 164). Okuyucu sanat yönünü takdir ettiği veya rol model aldığı yazarı günlüğ̈̈nden tanıdıkça onunla ilgili hayal kırıklığına uğrayabilir. Fakat her şeyden önce günlük okuyucusunun yazarları, sanatçı kimliklerinin yanı sıra kişisel zaaflarıyla birlikte kabul etmeleri gerekir. Nitekim yazarlar da günlüklerinde estetik kaygı taşımadan zaaflarını kabul ederek samimi duygularla kendilerini ifade ederler.

\subsection{Günlük ve Yansıtıcı Düşünce ilişsisi}

Günlük yazarları ifadelerinde samimidirler. Hatalarını, hayallerini, aşklarını, kaygılarını ve pişmanlıklarını açık yüreklilikle dile getirirler. Yadırganma, dışlanma ve küçümsenme kaygısı taşımazlar. Yazarların günlüklerinde dile getirdikleri metafizik kaygıları, pişmanlıkları ve çıkarımları birer yansıtıcı düşünce örneğidir. Yansıtıcı düşünmede öz düzenleme ve öz denetim vardır. Öz düzenleme ve öz denetimin estetik bir üslupla dile getirilmesi günlükleri nitelikli kılar. Günlüklerde yansıtıcı düşünceler anlamlı ve ardışıklı bağla sıralanır. Bu tür metinlerde sadece yaşanılan günlük olaylara veya olgulara ilişkin duygu ve düşünceler üzerinde durulur. Üzerinde düşünülen olay ve olguların doğruluğu mantıklı olup olmamalarına göre değerlendirilir. Burada önemli olan düşüncelerin içten ve samimi bir şekilde ifade edilmesidir.

Günlüklerdeki yansıtıcı düşüncenin temel felsefesi öz eleştiridir. Öz eleştiride bulunan yazar hayatıyla ilgili yeni çıkarımda bulunur ve doğru bilgiye ulaşır. Sanatçıların takdir edilen ve rol model alınan bütün yönleri temelde yansıtıcı düşüncelerin sağladığı bilgi, birikim ve tecrübeden kaynaklanır.

Günlüklerde genellikle eleştirel bir üslup vardır. Çünkü günlük olaylar sanatçıları sıkar, şaşırtır ve bunaltır. Hayatın dur durak bilmeyen ayrıntıları içinde, küçük fakat derli toplu bir âlemin 
düzenine uymuş sanatçının zekâsı huzur bulmaz (Emre, 2014: 42). Sanatçı, günlük hayatın düzenini beğenmez, sürekli günlük hayatla çatışan bir ruh hâli taşır. Günlük tutan sanatçının marazi ve bedbin ruh hâli vardır. Bu da doğal olarak üslubuna yansır. Günlüklerdeki eleştirel üslup temelde sanatçının ruh hâlinden kaynaklanır. Sanatçıların sosyal hayatla ilgili dışa dönük eleştirileri olduğu gibi içe dönük kendileriyle ilgili eleştirileri de vardır. Yansıtıcı düşünceler daha çok içe dönük bu eleştirilerle ilgilidir.

\subsection{Araştırma Kapsamında İncelenen Günlükler}

Türk edebiyatında Oğuz Atay, Adalet Ağaoğlu, Orhan Kemal, Muzaffer Buyrukçu, Tomris Uyar ve Buket Uzuner gibi yazarların da günlük türüyle kaleme aldıkları eserleri bulunmaktadır. Mevcut günlüklerin bir kısmı yazarların ölümlerinden sonra yayımlanmıştır. Bu araştırma, Ahmet Hamdi Tanpınar, Nurullah Ataç, Oktay Akbal ve Cemil Meriç'in günlükleriyle sınırlı tutulmuştur.

Türk edebiyatında şair, yazar ve eleştirmen olarak tanınan Ahmet Hamdi Tanpınar, günlüklerini 1953-1962 tarihleri arasında kaleme almıștır. Altı defterden oluşan günlükler Tanpınar'ın ölümünden sonra İnci Enginün ve Zeynep Kerman tarafindan yayımlanmıștır. Defterler, günlük görünümünde olmakla birlikte düşünce ve eleştiri yazıları içermektedir. İlk günlük 21.04.1953 tarihinde Tanpınar'ın Paris'e varışının üçüncü haftasında başlar. İkinci ve üçüncü defterdeki günlükler, Tanpınar'ın seyahati ile ilgili intibalarını anlatır. Dördüncü defter 1954-1956 tarihleri arasında; beşinci defter 26 Kasım 1958 tarihinde yazılmıştır. Altıncı defter ise Tanpınar'ın vefat ettiği 24 Ocak 1962 tarihinden son on üç gün öncesine kadar yazılan günlükleri içermektedir. Tanpınar'ın günlükleri vefatından sonra kardeşi Kenan Tanpınar tarafından Mehmet Kaplan'a teslim edilir. Mehmet Kaplan, bir dostun özel sohbetini andıran bu günlük sayfalarındaki bazı kısımların yanlış ve çarpık yorumlanmasından çekindiği için günlükleri uzun yıllar yayımlamaz. Fakat günlüklerde geçen "Bu defteri seviyorum. Benden sonra okunacağını düşünüyorum. Hoşuma gidiyor. Geçen zamanım görülecek sanıyorum” (Tanpınar, 2018: 134) ifadeleri Kaplan'ın kararını değiştirir. Günlükleri Zeynep Kerman ve İnci Enginün'e vererek yayına hazır hale getirilmelerini ister. Günlükler, araştırmacıların detaylı çalışmaları sonucunda 2007 yılında yayımlanır.

Türk edebiyatında eleştiri, çeviri ve denemeleriyle tanınan Nurullah Ataç'ın günlükleri 19531957 yıllarını kapsamaktadır. Ataç'ın 1 Ocak 1953’ten 11 Mayıs 1957'ye kadar yazdığı günlükler, ilk kez (1960) Varlık Yayınları tarafından yayımlanmıştır. Günlüklerin ikinci baskısı (1972) Türk Dil Kurumuna aittir. 1953-1955 yılları arasındaki günlükler 1. ciltte, 1956-1957 yılları arasındaki günlükler ise 2. ciltte toplanmıştır. Ataç "güncelerinde; genellikle dil konularını, sanatı-yazını, tiyatroyu-sinemayl, iletişim konularl ile bunlara bağll olarak görülen yaşam-ölüm gibi evrensel konuları ele alır" (Atabaş, 2011: 429). Feridun Andaç'ın ifadesiyle "Günce onun için zaman dilidir. Günlerin getirdikleri her zaman Ataç’ı ilgilendirmiştir. Bir düşün, bir yapıt, bir yazar, bir kültürel edim, dilsel yorum/bakışılyla onun gününe yansır" (2011: 229). Günlükler, Ataç'ın özel hayatına ve sanat anlayışına dair çok sayıda yansıtıcı düşünce içermektedir.

Gazeteci yazar Oktay Akbal (1923-2015), günlük türünü köşe yazarlığı kadar önemser. Kırk y1lı aşkın köşe yazarlığında bir günce tutar gibi okuyucularına seslenir. Çünkü günlüklerin zamanla belgesel özellikler kazanacaklarına inanır. Akbal'a göre samimi ve içten duygularla kaleme alınan günlükler, yazıldıkları çağın sosyal ve kültürel özelliklerini yansıtır. (1961: 788). Akbal, çocukluk yıllarından beri günlük tutmayı sevdiğini yıllar sonra kaleme aldığı bazı roman ve öykülerinde günlüklerinden yararlandığını dile getirir (1983: 217). Akbal, günlüklerini yıllar sonra okuyunca bazı kötü yaşantıların belleğinde zamanla güzelleştiğini fark eder. Ancak yazıya geçirdiği olayları, donup kaldığı için kaskatı ve acı halleriyle görmek zorunda kaldığı için üzülür (Akbal, 1983: 130). Oktay Akbal'ın "Günlerde" (1968), “Anılarda Görmek" (1972), "Yeryüzü Korkusu” (1974), "Yüzyıldır Umutsuzluk" (1991), "80’lerde Bir Yazar" (1992), adlı günlükleri bulunmaktadır. Araştırma kapsamında Akbal'ın “Anılarda Görmek" ve "Yeryüzü Korkusu” adlı günlükleri incelenmiştir. "Yeryüzü Korkusu", yazarın 1970-1975 yılları arasındaki günlüklerinden oluşmaktadır. Yazarın duygularını, pişmanlıklarını, yalnızlığını, içsel çatışmalarını anlattığı bu günlükler, sadece kendi yaşantısına değil aynı zamanda dönemin siyasi, sosyal ve kültürel olaylarına da tanıklık etmektedir. Oktay Akbal “Anılarda Görmek'te" 1965'ten 1969'a kadar geçen süreç içerinde yakın dönem Türk tarihiyle birlikte kişisel tarihini de sorgulamaktadır. Günlüklerinde dünle bugünü buluşturan yazar, bir film izletir gibi gördüklerini okurlarına yansıtmaya çalışır. 
Cemil Meriç 1955 ve 1983 yılları arasında aralıklarla da olsa yaklaşık 29 yıl günlük tutmuştur. Günlükler, Meriç'in ölümünden sonra oğlu Mahmut Ali Meriç tarafindan derlenerek "Jurnal I 1955-1965" ve "Jurnal II 1966-1983" adları altından yayımlanmıştır. "Jurnal'in" ilk cildinde Cemil Meriç’in günlükleriyle birlikte Rabia Hanım'a yazdığı aşk mektupları da vardır. "Jurnal'in" ikinci cildi ise yazarın 1966-1983 yılları arasında kaleme aldığ günlüklerden ve Lamia Hanım'a yazdığı aşk mektuplarından oluşmaktadır. Bu ciltteki günlüklerin düzenli bir yayın tarihi yoktur. Genç yaşta görme yeteneğini kaybeden yazar, günlüklerinde yaşadığı ruh hâlini, anılarını, itirazlarını, kişisel arayışlarını ve iç çatışmalarını bir arada sunmuştur. Günlükler, Cemil Meriç'in sırlarını paylaştığı yakın bir dostudu; yalnızlığında teselli kaynağıdır.

"Jurnal'ler" sürekli yazmak, üretmek ve yenilenmek isteyen bir düşünürün iç dünyasında verdiği mücadeleleri yansıtmaları açısından önemlidir.

\section{ARAŞTIRMANIN AMACI VE ÖNEMI}

Günlükler, yazarların sadece günlük olayları sıcağı sıcağına anlattıkları basit yapılı bir tür değildir. Onlarda yazarların estetik yargılarını, iç dünyalarını, pişmanlıklarını ve metafizik kaygılarını görmek mümkündür. Günlüklerde ayrıca yazarların hayat tecrübelerine dair bilgiler de bulunmaktadır. Dolayısıyla yazar araştırmalarında günlüklerden mümkün olduğunca yararlanmak gerekmektedir.

$\mathrm{Bu}$ çalışmada günlüklerde geçen yansıtıcı düşünceler tespit edilmektedir. Çalışmanın amacı, yansıtıcı düşüncelerin yazarların iç dünyaları ve hayat tecrübeleriyle olan ilişkisini ortaya çıkarmaktır. Günlüklerde tespit edilen yansıtıcı düşünceler, yazarları farklı yönleriyle tanıma firsatı sağlayacaktır.

\section{ARAŞTIRMANIN METODU VE YÖNTEMI}

Türk edebiyatında günlük türünde sınırlı sayıda eser kaleme alınmıştır. Bu çalışmada eleştirmen yönleriyle tanınan Nurullah Ataç, Ahmet Hamdi Tanpınar, Cemil Meriç ve Oktay Akbal'ın günlükleri incelenmektedir. Dolayısıyla araştırmada evren örneklem modeli kullanılmaktadır. Nitel araştırma metodunun uygulandığ çalışmada yansıtıcı düşünceler, doküman inceleme tekniğiyle tespit edilmektedir. Araştırma sonucunda tespit edilen bulgular, yazarların biyografileriyle ilişkilendirilerek değerlendirilmektedir.

\section{ARASTIRMANIN SINIRLILIKLARI}

Araştırmada Nurullah Ataç'ın "Günce I" ve "Günce II"; Cemil Meriç'in "Jurnal I" ve "Jurnal II"; İnci Enginün'ün ve Zeynep Kerman'ın "Günlükler Işığında Tanpınar'la Baş Başa"; Oktay Akbal'ın "Yeryüzü Korkusu" ve "Anılarda Yaşama" adlı günlükleri değerlendirilmektedir. Söz konusu yazarlar, günlüklerinde geçmişlerini sorgulamakta, pişmanlıklarını itiraf etmekte ve öz denetimde bulunmaktadırlar. Günlüklerde yazarların sanat, tarih, edebiyat ve siyasetle ilgili dışa dönük yansıtıcı düşünceleri de bulunmaktadırlar. Araştırmada yazarların içe ve dışa dönük yansıtıcı düşünleri değerlendirilmektedir.

\section{BULGULAR}

Araştırma kapsamında incelenen günlüklerde çok sayıda yansıtıcı düşünce tespit edilmiştir. Çalışmanın bu bölümünde tespit edilen yansıtıcı düşünceler örneklendirilecektir.

Yansitıcı düşüncenin temel felsefesi kişinin geçmişini sorgulaması ve doğru bilgiye tecrübesiyle ulaşmasıdır. İncelenen günlüklerde yazarların sık sık geçmiş hayatlarını sorguladıkları ve pişmanlıklarını dile getirdikleri görülmektedir. Özellikle Ahmet Hamdi Tanpınar'ın günlüklerinde pişmanlıklarıyla ilgili yansıtıcı düşünceleri çok daha belirgindir. Onun günlüklerde sürekli nevroz halini yaşayan, parasızlıktan ve yalnızlıktan şikâyetçi bir özne vardır. Metafizik kaygılar yaşayan bu özne, Tanpınar'ın kendisidir. "Bursa'da Zaman" şairi, bu denli rahatsız, huzursuz ve oldukça mutsuz olmasına rağmen yine de günlüklerinde sadece kendine odaklı edebî ve estetik kaygılarla yazdıkları üzerine düşünür (Esen, 2012: 103). Onun günlükleri genellikle anlık dikkatini ve tahassüslerini kaydeden kısa cümlelerle doludur (Koç, 2014: 164). Anlam derinliği olan bu kısa cümlelerde Tanpınar'ın hayat hikâyesine yansımayan iç dünyasına ait bulgular vardır. Tanpınar, günlügüünde "Geçtiğim yollara baklyorum. Bütün ömrüm etrafim ve kendim ile mücadele hiç olmazsa kendi kendimi hapis ile geçtiğini anliyorum" der (2018: 294). Tanpınar, benliğinden sıyrllıp duygusallıktan uzaklaştığı anlarda bu tür ifadelerle geçmişini sorgular. 
Tanpınar'ın sosyal hayatta beklediği itibarı görmediğinden dolayı çevresine karşı kırgınlıkları vardır. Edebiyat çevresine şöyle sitem eder: "Bugünkü edebiyat âleminde yüzde hiç olmazsa bes, fikirler benden. Benim adım yok ortada." (2018: 132). Fakat o, bu kırgınlıklarını dile getirirken kendisinden kaynaklanan eksiklikleri ve yanlışlıkları da fark eder. Günlügünde geçen şu ifadeler yansıtıcı düşünceden kaynaklanır: "Hakkımdaki sükût suikastının bir sebebi de belki benim. Edebiyatçılarla düşüp kalkmıyorum” (2018. 291); "Sosyali kaybetmiş olmanın cezasını çekiyorum. Beni şimdiye kadar ayakta tutan şeylerin hepsi kayboldular. Estetiğime inanmıyorum artık, çünkü her şeyi eskittiğimi hissediyorum" (2018: 159). Tanpınar'ın günlüklerinde insani zaafları açıkça görüldüğü gibi sürekli kendisini sorgulayan, hatalardan kendisine de pay çıkaran idealist ve realist yönü de görülmektedir.

Tanpınar geçmişe baktığında az çalıştığını, az ürettiğini düşünür. Günlüklerinde "Ben yalnız adamım ve bunu anllyorum. Fakat hakikaten bir şey yaptım mı? Yirmi sene evvelin şiir diline bir şeyler getirdim, ama bundan ne çıkar?" (2018: 63) veya "Az iş yapmadım. Fakat yaptıklarım beni tatmin etmiyor" (2018: 323) gibi ifadeler kullanır. Tanpınar'ın geçmişiyle ilgili pişmanlıkları çoktur. Günlüğünde şöyle der: "Neyim? Kimim? Nelere muvaffak oldum? Hiçbir şey yapamadim mı? Ah, bir kere olsun kendi dışıma çıkıp kendimi görebilsem! Neye yarar?” (2018: 73). O, günlüklerinde sürekli geçmişini sorgulayan ve kendini eleştiren bir ruh hâli içerisindedir. Fakat bu ruh hâli içerisindeyken kendini duygularının eseri etmez. Çalışması ve üretmesi gerektiğini bildiği için "Benim için mühim olan bundan sonrast ..." der (2018: 73). Vaktini sıkıntılı hülyalar yerine faydalı şeylerle geçirmesi gerektiğini düşünür. Boşa harcadığ zamanlar için de şöyle der: "Daima birkaç ay ötede hatta birkaç sene ötede yaşıyorum. Hülyaya sarf ettiğim saatleri çalışmaya sarf edebilsem" (2018: 102). Geçmişini sorgulayan Tanpınar, pişmanlık duygusu içerisindedir. Fakat geleceğe dair ümitleri vardır. Günlüğünde iç muhasebesini yaparken kullandığı şu ifadeler de dikkat çekicidir:

"Zaman azald, sermayeyi israf devri geçti. Sihhatli bir iç âlem rejimi. Ye'se kapılmamak lazım. Her okuduğunu kendine çevrilmiş bir silah yapmaktan vazgeç. Yapabileceğini yap; azami gayretinle yap. Olura bağlama, çalış, güçlüğü atlama, ara, değiştir ve bul; fakat lüzumsuz yere kendini zehirleme. Sanatkârın kendisini tenkidi intihar şekline gitmemelidir... Bir ihtiyarın da sevebileceği şeyler vardır. Sevgi kapısı kapanmaz, unutma... Geç kaldım deme... Yalnızlı̆̆ını iyice yokla ve beyhude ile doldurma. Yalnızlığın seni asla götürür. Allah'a ve muadiline” (2018: 239).

Tanpınar, geçmişini sorgularken yıkıcı olmamaya çalışır. Kendisini hayatın gerçeklerinden koparacak söylemlerden uzak durur. Onun idealinde sürekli, düşünen, üreten ve itibarı olan bir "ben'e" ulaşma çabası vardır.

Tanpınar'ın yansıtıcı düşüncelerde bulunduğu bir başka konu evlilik hayatıyla ilgilidir. Ellili yaşlara geldiğinde eş ve evlat eksikliğini daha da derinden hisseden yazar, günlügüünde şöyle der: "Keşke evlenmiş olsaydım ve ferdi saadet düşüncesi kafamda bu kadar zalim bir hedef olmasaydl. Bir duvarın arkasında gibi yaşıyorum" (2018: 65). Kendisini sorguladıkça eksikliklerini, hatalarını fark eden Tanpınar, yaşadığı sorunlara çözüm üretme gayreti içerisinde olmuştur. Onun günlüklerinde bir yandan sorgulayan, eleştiren bir yandan da onaran, üreten ve tutunan iki karşıt tematik güç vardır. $O$, yansitıcı düşündüğü anlarda onaran, üreten ve tutunan tematik gücün temsilcisidir. Edebiyatın hemen hemen her alanında çok sayıda nitelikli eser kaleme alan Tanpınar, günlüklerinde sanatçı, akademisyen ve siyasetçi kimliğinin dışında hayalleri, aşkları, hırsları ve kırgınlıkları olan sade bir vatandaş kimliğiyle konuşur. Onun günlüklerindeki iç konuşmaları söylendiği sosyal ve psikolojik şartlarda değerlendirmek gerekir.

Türk edebiyatında günlük türü denilince akla ilk gelen isimlerden biri de Nurullah Ataç’tır. Ataç, 1 Ocak 1953 yılında kaleme aldığı günlüğünde çocuk yaşlarda günlük tutmamanın pişmanlığ 1 içerisindedir. Günlüğünde şöyle der: "Bu yaştan sonra başlanır mı öylesine? İsterdim doğrusu, benim de çocukluğumdan, hiç olmazsa gençliğimden beri tutulmuş bir güncem olsun isterdim. Kendi kendimi bulurdum onun sayfalarında" (1998a: 11). Ataç günlüklerinde Monsieur Guinea'dan etkilendiğini açıkça dile getirir. Günlüğünde özentinin bir sanatçı için eksiklik olmadığını savunur.

Nurullah Ataç, aruzla şiir yazan şairleri ve bu şiirlerden zevk alan okurları bir dönem eleştirse de zamanla bu düşüncelerinin yanlışlığını fark eder. Günlüğünde konu hakkında şöyle der:

“Düşünüyorum da: 'Asıl onlar hakl değil mi?' diyorum kendi kendime. Bir ezgi dinler, bir 
bülbülün ötmesini dinler, bir törenin hiç değişmez, anlaşılmaz sözlerini dinler gibi dinliyor onlar şiiri, böylece de șiirin özüne, ta kaynaklarına gitmiş oluyorlar. Biz yanıllyoruz, şiirde bir yenilik, yeni bir görüs, yeni bir duyuş, yeni bir düşünüs, yeni yeni biçimler aradığımız için biz yanılıyoruz. Ama olmuş bir kere olanlar, ayırmışız şiiri kaynaklarından, bir tören olmaktan çıkarmışız onu, kendimize göre bir şiir anlayışı kurmuşuz, artık onlarla, onların şiirleriyle uzlaşamayız, o şiirle yetinemeyiz, onların acunu bize, bizim acunumuz onlara kapalı" (1998a: 14).

Ataç, 27 Ocak 1953 tarihli günlüğünde klasik şiire karşı gösterdiği tepkiyi haksız bulduğunu dile getirir: "Şiirden anlamak değildir elbette bu, ama bunu yıkmaya kalkmak hakkımız mıdır? Acaba en doğru şiir anlayışı, şiir karşısında en doğru davranış o değil midir? Bizler, bir yandan şiirde manaya bakılmaz diyoruz, bir yandan da o gibi şiirleri, manaya bakmaksızın sevenlere kizıyoruz!" (1998a: 23) Ataç 8 Ocak günlüğünde de "Ben ne dersem diyeyim, o taze şiirin 'itibarı bâki' kalacak." ifadelerini kullanır (1998a:37).

Ataç, "Günce'sinde" Cumhuriyet sonrası Türk şair ve yazarları hakkında da yansıtıcı düşüncelerde bulunur. Bir dönem Hüseyin Rahmi Gürpınar'ın öykülerini Halit Ziya Uşaklıgil'in öykülerinden daha üstün tuttuğunu dilen getiren yazar, sonraki okumalarında Uşaklıgil'in daha gerçekçi ve nitelikli öyküler kaleme aldığını söyler:

"Ben de bilineyim (itiraf edeyim) suçumu, uzun yıllar Hüseyin Rahmi'nin öykülerini Halit Ziya Uşakllgil'inkilerden üstün tuttum. 'Bizi daha iyi gösteriyor onlar.' dedim. Geçenlerde Mürebbiye'yi yeniden okumaya kalktım, okunmuyor, dayanılmaz bir bayağllı̆̆ var. Hüseyin Rahmi'nin öyküleri, bizim o yıllardaki yaşayışımızın gözgüsü (aynası) imiş, onlarda birer belge niteliği varmış. Öykücüye, yazara düşen, ortaya belge yı̆̆mak mıdır? Öyle olsa bile öteki öykülerin de birer belge niteliği yok mudur? Belli bir çağda, bir toplumun nite yaşadığını göstermiyorsa bile ne türlü yaşayışa özendiğini, neler kurguladığını gösteriyor" (1998b: 136).

Ataç'ın Refik Halit Karay'la da ilgili ön yargıları olmuştur. 30 Mart 1954 tarihli “Bay Refik Halit Karay sevdiğim yazarlardan değildir” diyen Ataç, bir gün sonraki günlüğünde şöyle der:

“Dün sinemada Nilgün'ü gördükten sonra Bay Refik Halit Karay'ı düşündüm. Sevmesine sevmem ya, öyle bir filmin başında adl görülecek yazarlardan da değildir, ondan çok yüksektir. Kirpi'nin Dedikleri, doğrusu, cesaretli yazılardı. Unutmayalım ki Bay Refik Halit Karay, bugün çok kimselerin yazdığı, 'yaşayan dil' dediği Türkçeyi kuranlardandır" (1998a: 184).

Ataç, günlüklerinde bazı şair ve yazarlarla ilgili ön yargılarını açık yüreklilikle dile getirir. Bir dönem beğenmediği, eleştirdiği yazarları tanıdıkça ve eserlerini okudukça onlara karşı ön yargıları değiş̧ir. Nurullah Ataç, günlüklerinde okuma kültürüyle de ilgili yansıtıcı düşüncede bulunur. Günlüğünde verdiği bir örnekle kendisini eleştirir:

"Ben de sanki ne diye okuyorum o Simenon un kitabını? Biliyorum neden okuduğumu, birtakım yazarlar, benim de sevdiğim yazarlar onu övdüler de onun için okuyorum. Monsieur Gide bile onu beğendiğini söylerdi. Aldanmış, o da birtakım pırıltılara kapılmış... Şu 'polis romanları' merakı da böyle bir aldanmadan doğuyor; hiçbiri, hiçbiri ilginç değil o romanların, hepsi de boş şeyler. Ben de birçoğunu okudum. Pierre Very'ninkileri, Dorotby Sayers'inkileri, Agatba Christie'ninkileri beğendiğıimi, güzel bulduğumu sandım, kendi kendimi aldattım" (1998a. 16).

Ataç, entelektüel bir yazardır ve seçici bir okurdur. Günlüğünde bir dönem popüler kültürün etkisiyle kitaplar okuduğunu ve bunda da yanıldığını dile getirir. Ataç'ın okuma kültürüyle ilgili yansıtıcı düşünceleri bilgi, birikim ve tecrübesinin kaynaklarını göstermesi açısından önemlidir.

Ataç'ın günlüklerinin ana teması öz Türkçedir. Günlüklerinde konuşma ve yazı dilinin birliğini savunur. Dille ilgili savunduğu görüşlere yansıtıcı düşüncelerle sahip olmuştur. Günlüğünde şöyle der.

“Özenmesine özeniyoruz ya, başarabiliyor muyuz? Bizim yazılarımızın dili bir mi konuşma diliyle? Çarşıda pazarda konuşulan dille? Doğrusunu söyleyeyim: Başaramıyoruz. Biz okuryazarlar konuşma Türkçesini unutmuşuz, yitirmişiz de onun için başaramıyoruz. Biz de okula gittik çocukluğumuzda, bize de ögrrettiler yazı dilini, kesin kuralları bellettiler, fiil hep sona gelmelidir dediler, biz de inandık, belledik o dersi, kafamız öyle yoğruldu, o kurallara göre konuşmaya başladık. Kitaplar okuduk: Onlar da bize ögretilen kurallara göre yazılmıştı, dilimiz gerçekten öyledir sandık. 
Sonra da dinledik çarşı pazar konuşmasını. Baktık ki kitaplardaki dilden daha açık o, daha canlı, daha sicak" (1998a: 43).

Öz Türkçe savunucusu olan Ataç'ın kendisiyle ilgili bir başka öz eleştirisi üslubuyla ilgilidir. Ataç, yazılarında öz Türkçe adı altında türettiği sözcüklerin anlaşılmadığını itiraf ederek bu noktada kendisini eleştirir:

"Geçen, genç yazarlarımızdan biriyle konuşuyordum, o takıldı buna. 'Neden değiş̧tiriyorsunuz böyle? Sizden ögrrenenler var, şaşırtıyorsunuz onları.' dedi. Böyle düşünmeyi doğru bulmuyorum ben. Biz yeni dilin kuruluş çağındayız, bocalamalarımız olur, yanılmalarımız olur. Birtakım kavramlara Türkçe adlar artyoruz, buluyoruz bir ad, sonra baklyoruz ki o ad o kavrama gerçekten uymuyor, başka bir anlamı var, ya da başka bir anlam yükleniyor" (1998b: 132).

Ataç, ideolojik bir söyleme dönüştürdüğü öz Türkçe hakkındaki görüşlerini günlüklerinde bu şekilde sorgulamaktadır. Ataç'ın dil ve üslubu Yakup Kadri Karaosmanoğlu, Ahmet Hamdi Tanpınar, Cemil Meriç gibi dönemin bazı yazarı tarafından eleştirilmiştir. Günlüklerdeki yansıtıcı düşünceler, onun da bu konuda kendisini eleştirdiğini göstermektedir.

Ataç'ın sağlığıyla da ilgili pişmanlıkları vardır. Şeker hastalığına yakalandığı süreçte yaşadığı ruh hâlini günlüklerinde anlatır. İlk dönemlerde doktorların tavsiyelerine uymakta zorlanan Ataç, zamanla doktor tavsiyelerinin önemini daha iyi anlamıştır. 7 Ekim tarihli günlüğünde sağlığıyla ilgili pişmanlıklarını anlatır:

"Eskiden böyle şeylere kazanamayacă̆ımı, ucunda ölüm de olsa tembihlere, öğütlere uymayacă̆ımı sanırdım. Meğer insan ne kadar da bağlanıyormuş hayata! Yaşasın, soluğunu alsın versin de ne türlü olursa olsun! Bunda, bu ölüm korkusunda bir küçüklük, mızmızlı olduğunu da sezmiyor değilim” (1998a: 113).

Ataç, sosyal hayatın içindedir. Günlüklerinin büyük bir kısmında dışa yönelik eleştiriler yapar. Günlüklerinde ara ara dış dünyanın iç dünyasına bakan yönlerini de anlatır. Gaziantep, Kahramanmaraş, Adana ve Antakya'ya gibi bazı illeri ziyaret eden Ataç, bu yerleri daha önce gezip görmediği için üzülmüsstür. Bu üzüntüsünü yine yansitıcı düşüncelerle dile getirir: "Gençliğimde, yorgunluğa dayanabildiğim günlerde niçin yolculuğa çıkmamışım? Aklıma bile gelmezdi. Hep terstir benim işlerim. Gençlikte yapacaklarımı yaşlılık günlerime bıraktım...” (1998a: 402). Ataç günlüklerinde küçük, sırdan ve basit dertlerini anlatır. Okuyucu onun dertlerinde, pişmanlıklarında ve itiraflarında kendinden bir şeyler bulur.

"Yeryüzü Korkusu” ve “Anılarda Görmek” günlüklerinin yazarı Oktay Akbal'ın asıl mesleği gazeteciliktir. Hayatının büyük bir bölümünü köşe yazarlığı yaparak geçiren Akbal'ın günlüklerinde özel hayatına, hayat felsefesine ve mesleğine dair yansitıcı düşünceler bulunmaktadır. Günlüklerine göre Akbal, mesleğinde yansitıcı düşüncelerle ilerlemiş̧tir. Köşe yazarlı̆̆ 1 yaptığı dönemde sürekli kendisini sorgulayan ve eleştiren bir yanı vardır. "Yeryüzü Korkusu” günlügünde şöyle der:

"Dizi dizi sabah gazeteleri. Daktiloya kâğıdı taktım. Bekliyorum ilk cümleyi. Bilmiyorum nasıl olacağını, neden söz açacağımı, neyle başlayıp neyle bitireceğimi. Gazetelerde haberler, başlıklar çığllk atıyor. Beni yaz, beni yaz, beni yaz. Yüzlerce yazı konusu. Bir çırpıda dolacak sayfa. Ama üç beş dakikada okunup atılacak bir yazı, birçok yazı. Ne çok yazıyorlar böylelerini. Ben de yazıyorum ya! Yazık ediyoruz kendimize. Bunu, daha başarıl yazılar, yapıtlar ortaya koyabilecekken bunu yapmayıp gündelik olaylar yazanlar için söylüyorum" (1983: 13-14).

Akbal, mesleğini sorguladıktan sonra farklı türde daha kalıcı eserler vermesi gerektiğini düşünür. Yazarın şiir, öykü ve roman türünde kaleme aldığ 1 eserler bu yansitıcı düşüncesinin birer sonucudur. Akbal'ın “Anılarda Görmek” günlüğünde köşe yazarlığıyla ilgili yansıtıcı düşünceleri vardır. Şöyle der.

“Vatan'da sekiz yıldır çıkan fikralarım iki çekmeceyi dolduruyor. Üstelik çoğu yok. Zamanında kesip saklamak gerekirdi, yapmamışım. Şimdi o yazlları koleksiyonlarda arayıp bulmak gerekecek. Gazete yazıları deyip geçmişim. Oysa 1956'dan bu yana hemen hemen her gün yazdığım bu fikralar günce yaprakları gibi. Çoğu gündelik politikanın akışını izleyen yazılar. İnönü, Menderes, Bayar, Gülek, Gümüsspala, Alican vb. ünlü kişilerin adları bol bol geçiyor. Unutmuşum neler yazdığımı, şaş̧ın şaşkın okuyorum yeniden. Neler olmuş, neler geçmiş! Neler yazmışım! Yıllar 
akıyor, gene aşă̆ yukarı aynı şeymiş, birtakım harfler yer değiştirmiş, yeni partiler kurulmuş" (Akbal, 2004: 68). Yazılarında tekrara düşme endişesini taşıyan Akbal, sürekli eski yazılarını sorgular. Neyi, niçin ve nasıl yazdığını düşünür. Yazılarında yeni fikirler ortaya koymak için eski yazılarını göz önünde bulundurur.

Oktay Akbal, günlüklerinde yurt dışı seyahatlerini anlatırken dış dünyadan çok iç dünyasına yönelir. Tayland'ın başkenti Bangkok'a gittiğinde kaldığı konforlu lüks mekânı İstanbul'da yaşadığg mekânla karşılaştırır. Akbal, günlüğünde Levent’teki bahçelerin güzelliğinden ve yeşilliğinden söz eder. Geçmişi ana transfer eden yazar, sahip olduğu güzelliklerin farkına varır. Bu farkındalıkla günlüğünde mutluluk özlemini dile getirir:

"Saat benim saatimle beş buçuk, Bangkok'a geliyoruz, burada saat sabahın onu. Kahvaltı geldi. Pirzola, omlet, reçel. Karmakarışı bir yemek. Biraz yenmeli. Levent'te de kalktınız, bahçe yemyeşildir, sabah yeşili. Şöyle huzurlu, tatlı bir yaşam süremedik diyorum. Yaşamadık istediğimiz gibi. Yaşamayacak mıyı hiç?" (1983: 31-32).

Oktay Akbal'ın ellili yaşlara geldiğinde söyledikleri dikkat çekicidir: "Korkuları büyütmek, sorumlulukları ağırlaştırmak, yaşamdan kaçmak... Bütün bunların ne denli yanlış olduğunu anlamak için elli yaşa gelmek gerekliymiş." (1983: 135). Akbal, geçmişini sorguladığında hayat yükünü boş yere ağırlaştırdığının farkına varmıştır. 30 Haziran 1973 tarihli günlüğünde "Nerede 1973 'teki ben, nerede 1946'daki. İki yabancı birbirine... Tanlyamazlar birbirini..." ifadelerini kullanır (1983: 139).

Akbal'ın günlüklerinde sürekli sorgulayıcı bir tavrı vardır. $O$, bunu yaparken ya bir obje ya bir olay ya da bir olgudan ilham alır. Eski defterini karıştırırken defterin arasında bazı notlar bulmuştur. Bu notları niçin tuttuğunu hatırlamayan yazar bu konuda kendisini eleştirir:

"Yazmışım bunları bir kâğıt üstüne. Defterin arasina koymuşum. Hem de bu temmuz gününün yaprağına. Bir şeyler duymuş düşünmüş olmallyım bunları not ederken. Neydi acaba? Hatırlamam imkânsız. Yalnız bu alıntıları değil, o an duyduklarımı da yazmalıydım. Şimdi şu sözleri okudukça, üstlerinde düşündükçe bambaşka, yepyeni şeyler çağrıştırlyor bende. Ama en çok 'Hiçbir suçlu kendi yargıçlığından kurtulamaz' mısraını beğendim. En acımasız yargıç kuşkusuz kendimize. Gerçekten bir insan olmuşsak, olabilmişsek... (Akbal, 1983: 41).

Akbal, günlüklerinde öykücülük yönünü de eleştirir. Öykülerinde tekrara düştüğünü ve karamsar ruh hâlini öykülerine yansıttığını söyler. Günlüğünde duygularını sıcağı sıcağına anlatır:

"Girdim içeri, yatağa uzandım, güneş çekiliyor yavaş yavaş. Son öykülerimden birini buldum. Nasıl da umutsuzmuşum, nasıl da yenikmişim, durup dururken 'Yok düş yok, hayal yok. Anlam aramak yok. Ölüm, o var işte. Bugün yarın... Şu kapının, bu yolun ardında. Şu merdiveni inince, karşıki yola çıkınca. 'Şimdi ölüm diye bir şey yok. Zor yakalar beni! Kaçacağım ölümden de, ölümsü duygulardan da... Ne gereği var yaşamak dururken ölmeyi istemenin, beklemenin...” (1983: 112). Akbal günlüğünde daha önce hissettiği umutsuz ve ölümsü duyguları hatırlar, yansitıc1 düşüncelerle öykücülük yönünü sorgular.

Akbal, "Anılarda Görmek” adlı günlüğünde de öykücülük yönünü eleştir. Çeşitli yargılar, çeşitli değerlendirmeler, çeşitli görüşler taşıyan bu öyküleri artık beğenmediğini söyler. Bu konudaki yansitıcı düşünceleri şöyledir:

“On yıl, yirmi yıl önce yazdĭ̆ım öykülerle bugünkü 'ben' arasında hem yakınlı, hem de öylesine bir yabancılık var ki! O öyküleri yazmışım bir kez, onlar kendi yaşamlarına alışmışlar, çeşitli yargılar, çeşitli değerlendirmeler, çeşitli görüşler karşısında yalnızlar şimdi. Öylesine yalnızlar ki ben bile yanlarında değilim, zaman zaman karşılarındayım!” (Akbal, 2004: 26).

Oktay Akbal "Yeryüzü Korkusu" ve "Anılarda Görmek” günlüklerinde yazarlık yönünü, sosyal ilişkilerini, siyasî ve edebî görüşlerini sorgular. Hayat tecrübesini anlattığ 1 günlüklerinde yansıtıcı düşüncelerle sosyal mesajlar vermeye çalışır.

Hayatı gönül gözüyle okuyan Cemil Meriç'in de günlüklerinde geçmişiyle ilgili pişmanlıkları vardır. O, bilgi birikim ve tecrübesini pişmanlıklarından çıkardığı dersler üzerine inşa etmiştir. Kaygı ve korku psikolojisiyle kaleme aldığı günlüklerinde pişmanlıklarını yansıtıcı düşüncelerle anlatır. Cemil Meriç, görme duygusunu yitirdikten sonra hayata daha karamsar bakar. Duygularının esiri olmamak için de sürekli üretmeye, sosyal hayatın içinde olmaya çalışır. Bedbin 
ruh hâli içinde bulunduğu anlar için "Uzun sürmüyor. Uzun sürse deliririm" ifadelerini kullanır (2014: 318). Meriç, "Böyle zamanlarda çevremi kırmamak için bütün terbiyemi, bütün insanlı̆̆ımı ne kalmışsa- seferber etmem gerekiyor" der (2014: 319). Jurnal yazarı, bendin anlarında enerjisini yine iç dünyasından alır. Mümkün olduğunca karamsar duygulardan ve çaresizlikten kurtulmaya çalışır. Bütün olumsuz şartlara rağmen hayata tutunması gerektiğini düşünür. Günlüklerinde geçen "Evet, kör bir kuyuya düşer gibi oluyorum zaman zaman. Dış dünyayla bağlarımı koparmamam lâzım. Her şeye rağmen sevmek... Herkesi sevmek. Karımı, çocuklarımı, dostlarımı. Ölmeden önce ölmek çok cazip" (2014: 260) ifadeleri onun zorluklara karş1 direnen yönünü göstermektedir.

Meriç, günlüklerinde dertleri, hayalleri ve idealleri olan üçüncü bir şahıstan söz eder. Bu şahıs, genç yaşta gözlerini kaybeden Cemil Meriç’ten başkası değildir. 02. 02.1963 tarihli günlüğünde duygularını dile getirirken şöyle der: "Bazan şükrediyor körlüğ̈̈ne. Felaketine dört elle sarllmak istiyor. Körlük bir nevi ölüm. Hayır, ölümden çok daha beter bir işkence. Öldükten sonra yaşamak gibi bir şey" (2014: 87). Genç yazar, içine kapandığı anlarda mantıklı ve realist olmaya çalışır. Jurnal I'de geçen "Felaketlerimiz üzerinde durmak, dikkatimizi fizik ve manevi yaralarımıza teksif etmek bizi köstebeklerle aynı seviyeye indirir" (2014: 44) ifadeleri, Meriç'in mantıklı ve realist yönünü göstermesi bakımından önemlidir.

Günlüklülerinden anlaşıldığına göre Cemil Meriç, hassas ve kırılgan bir ruha sahiptir. Körlük psikolojisi iç dünyasını oldukça etkilemiştir. Fakat o, bu psikolojiden yansıtıcı düşüncelerle kurtulur. "Sanatkâr yaralarını göz önüne sererek merhamet dilenen bir çanak yalayıcı değildir" (2014: 108) sözleri onun dirayetli ve idealist yönünü gösterir. 6 Mart 1983 tarihli günlügünde de "Gözlerimi kaybettikten sonra ideal bir mutluluk düşünemezdim. Ama hayatı yine de seviyordum. Zilletleri, korkuları, bitip tükenmeyen endişeleri ile” der (1998: 343). Meriç görme yeteneğini kaybetmekle iç dünyasında buhranlar yaşamıştır. Fakat o, bu ruh halinin esiri olmayıp sürekli üretmiş; kendisini yenilemiş; zorluklar karşısında mücadele etmeye çalışmıştır.

Günlüklerinden anlaşıldığına göre Cemil Meriç, duygusal bir insandır. Gençlik aşklarını, hayallerini, ümitlerini samimi duygularla anlatır. "Quınze-Vıngt Geceleri” başlıklı günlügünde geçmişte yaşadığı aşkları tek tek itiraf eder. İçindeki boşluğu doldurmak için aşka yönelen Meriç günlüğünde şu itiraflarda bulunur:

"Sevmek zorundaydı. Yirmi iki sene kadınsız yaşamıştı. Kadınla nasıl konuşulur bilmiyordu. Güveni yoktu kendine. Hiç mi hiç güveni yoktu. İzdivaç teklif edebileceği her kadına evlenelim dedi. Ne yapabilirdi başka? Başka şekilde bir kadına sahip olabilmeyi aklından geçiremiyordu ki. Bütün kadınlar reddettiler. Bütün kadınlar" (2014: 102).

Romantik duygular içinde yazılan günlükler Meriç'in hassas, kırılgan ve arayış içinde olan ruhunu yansitmaktadir.

Cemil Meriç, günlüklerinde ailesine karşı sorumluluklarından da söz eder. Yansitıcı düşüncelerinden anlaşıldığına göre çocuklarının yüzüne karşı dile getiremediği pişmanlıklarını ve hatalarını günlüklerinde dile getirmiştir. Vaktinin büyük bir bölümünü okumaya, araştırmaya ayıran Meriç, uzun yıllar çocuklarını ihmal ettiğini düşünmüştür. Günlüğündeki şu ifadeler açık yüreklilikle dile getirdiği itiraflarıdır:

"Çocuklarıma tereddütlerimden, istifhamlarımdan ve bedbinliklerimden başka miras bırakamayacak mıyım? Marx doğru söylüyor, evvela mürebbinin terbiyeye ihtiyacı var (2014: 207). Meriç, geçmişini sorguladığında çocukları için gerektiği ölçüde verimli olmadığını düşünmektedir.

Cemil Meriç, 23.2.1963 tarihli "Bir Babanın Şikâyetleri” başlıklı günlüğünde babalık yönünü sorgular. Oğluna hitaben yazdığı günlüğünde şöyle der: "Hafizanda çatık kaşlı bir hatıra olarak yaşamak istemezdim” (2014: 120). Suçluluk psikolojine kapılan Meriç, günlüğünün sonunda yansıtıcı düşüncelerini dile getirir: "Mazim günahlarla dolu, hatalarla dolu. Ama yoluma lşık tutan olmadı. Olsa ne değişecekti bilmem. Ne var ki çocuklarıma karşı bilerek hiçbir kusur işlemedim. Hatalarım cehaletimden" (2014: 120). Çocuklarına karş1 sorumluluklarını yerine getirmediğini düşünen Meriç, pişmanlık duygusu içerisindedir. Bu konudaki yansıtıcı düşünceleri hayatının bir dönemiyle sınırlıdır. Meriç yansıtıcı düşüncelerin sağladığı tecrübeyle aile ilişkilerinde başarılı ve faydalı olmaya çalışmıştır.

Cemil Meriç, sürekli okuyan ve sürekli üreten entelektüel bir yazardır. Günlüklerinden 
anlaşıldığına göre okuma ve yazma heyecanını kendi iç dünyasından alır. Bunu da sağlamak için yansıtıcı düşüncelerde bulunur. "Kırk Ambar" yazarı, kendisini sorguladıkça daha fazla okur ve daha fazla da üretir. Yansitıcı düşünce örnekleri arasında şöyle der: "Uyku ile uyuşukluk arasında rakseden bir hayat. Beklediğim bir şey yok. Dersler tatsızın tatsızı. Kendimi bir işe bağlayamadım. Felâket şurada ki bu günler de sınırl. Çalışmam gereken saatlerde paçavralaşmıı̧ bir idrakle baş başayım" (2014: 147); "Hayır hayır... Bu çemberi mutlaka parçalamalı, kendimi verebileceğim bir işe başlamalıyım. Öyle bir durumdayım ki utandığım için yataktan kalkıyorum. İzzet'ten utanıyorum. Sonra? Sonrasi yok" der (2014: 147).

Meriç 31. 12. 1963 tarihli günlügünde bir yıllık hayat serüvenini değerlendirir. "Bir Yılın Bilançosu" başlıklı günlüğünde ulaşamadığı hedefleri ve gelecek yıla dair beklentilerini anlatır. 1963 yılını verimsiz ve faydasız geçirdiğini düşünür. Bu yılda birkaç kitap okumuş, sadece iki konferans vermiş, "Emile" tercümesini ve "Hint Edebiyatı'nı" yayımlamamıştır. Bunları da kendisi için yetersiz görür. Günlüğünde bir yıllık mazisini şöyle anlatır:

"Geçen yıl içinde birtakım ümitlere kapıldım. İtiraf edilen veya edilmeyen ümitler. Hiçbiri gerçekleşmedi. Ama herhangi bir felakete de uğramadım. 1963 yılı hayatımın kötü yıllarından biri sayılmaz. Çok zaman kaybettim. Çok zaman ve biraz ümit. Yaşamak da bu galiba” (2014: 285).

Geçmişini sorgularken pişmanlıklarını dile getiren Meriç'in gelecek yılla ilgili ümitleri vardır. Gelecek yıla dair hayallerini metaforlarla anlatır: "64'e büyük ümitlerle girmiyorum. Hiçbir programım yok. Yol, yola çıtıtıktan sonra belirir. Balta girmemiş bir orman, istikbal. Hangi tarafa sapacaksın? Cihangirlik rüyalarl görmüyorum artık" (2014: 285).

Cemil Meriç "Bir Yılın Otopsisi” başlıklı günlüğünde de yansıtıcı düșüncelerini dile getirir: "Korkular, vehimler, vesveseler... Takvimden koparılan yapraklarla yok olan bir yıl. Dış âlemde hiçbir değişiklik yok" der (1998: 313). 1981 yılında "Yeni Devir" gazetesinde çıkan "aydın", "Batılaşma", "kültür ve ideoloji" konulu birkaç makale dışında yeni fetihler gerçekleştiremediği için kendisini yine eleştirir. "Kırk Ambar'ın” ödüle layık görülmesi ise onu mutlu etmiştir.

Meriç, engelli olmasına rağmen sürekli sosyal hayatın içindedir. Davet edildiği konferanslara, panellere ve seminerlere mümkün olduğunca katılmaya çalışır. Bu sebeple geniş bir sosyal çevresi vardır. Günlüklerinde yakın çevresiyle de ilgili yansıtıcı düşüncelerde bulunur. Bir dönem tavırlarını, üsluplarını veya eserlerini eleştirdiği sanatçı dostlarını sonradan yansıtıcı düşüncelerle tekrar değerlendirir. Çünkü onların da kültürel birikimine katkı sağladığını düşünür. Eleştirdiği yakın dostu İzzet Bey için şöyle der: "Ama hayatımızı tanzim eden onlar. İzzet olmasa ne Hint yazılabilirdi, ne Jurnal. Her ibda sayllamayacak kadar çok âmillerin eseri" (1998: 313). Günlüklerdeki bu tür ifadeler yazarın kadirşinaslığını göstermesi bakımından önemlidir.

\section{SONUÇ}

Araştırma kapsamasında incelenen günlüklerde yazarların sık sık kendilerini sorguladıkları ve pişmanlıklarını dile getirdikleri tespit edilmiştir. Yazarlar öz eleştiri yaptıkça doğru bilgiye ulaşmakta ve hayatlarıyla ilgili yeni yeni kararlar almaktadırlar. Günlüklerde yazarların özel hayatları, siyasî görüşleri ve sanat anlayışlarıyla ilgili yansıtıcı düşünceleri bulunmaktadır.

Nurullah Ataç, günlüklerinde genellikle sanat anlayışıyla ilgili yansıtıcı düşüncelerini dile getirir. Eski geleneğe karşı olup öz Türkçenin kuvvetli bir savunucusu olan Ataç, günlüklerinde bu konuda ön yargılarının olduğunu itiraf eder. Yazar, okudukça doğru bilgiye ulaştı̆̆ını ön yargılarından kurtulduğunu dile getirir. Günce yazarı, bir dönem sanat yönünü Hüseyin Rahmi Gürpınar'dan daha düşük gördüğü Halit Ziya Uşaklıgil'e haksızlık ettiğini; beğenmediği Refik Halit Karay'ın asında Türkçe'nin gelişimine büyük katkı sağladığını itiraf eder. Nurullah Ataç'ın günlüklerindeki bu tür dışa dönük yansıtıcı düşünceler, Türk eleştiri tarihi açısından önemlidir.

Tanpınar'ın yansıtıcı düşünceleri genellikle metafizik kaygılardan kaynaklanır. Parasızlık ve yalnızlık Tanpınar'ın en büyük ızdırabıdır. Fakat o, yansıtıcı düşündükçe kendisinden kaynaklanan hatalarının farkına varır. Günlüklerinde sosyal çevresinden uzaklaştığı, zamanında evlenmediği ve az okuyup az ürettiği için kendisini eleştirir.

Cemil Meriç'in yansıtıcı düşünceleri Tanpınar'la benzer özellikler göstermektedir. Her iki 
yazarın da benzer sıkıntıları ve benzer psikolojik özellikleri vardır. Cemil Meriç de günlüklerinde sık sık yalnızlık psikolojisinden, metafizik kaygılarından ve beklediği itibarı görmemesinden söz eder. Onun da günlüklerinde gelecekle ilgili kaygıları vardır. Fakat o, bu tür kaygıların esiri olmak istemez. Yansitıcı düşüncelerle üretmesi ve hayata tutunması gerektiğini bilir. Sürekli yazması ve üretmesi bu bilinçten kaynaklanır

Oktay Akbal'ın yansıtıcı düşünceleri ise genellikle gazetecilik mesleği ve sosyal hayatıyla ilgilidir. Akbal'ın eline geçen firsatları zamanında değerlendirmemesinden kaynaklanan pişmanlıkları vardır. Günlüklerinde yeni bir şeyler üretmek, tekrara düşmemek ve özgün olmak için sürekli arayış içinde olduğu görülür. Gazeteci yazar Oktay Akbal, yansıtıcı düşündükçe mesleğinde ilerlemiş farklı türde özgün eserler kaleme almıştır.

Araştırma kapsamında incelenen günlüklerin ortak teması pişmanlıklardır. Yazarlar pişmanlıklarını açık yüreklilikle itiraf etmişlerdir. Araştırmadan çıkan ortak sonuca göre pişmanlıklar ve itiraflar yazarların iç dünyalarını olgunlaştırmaktadır. Yazarların eserlerindeki estetik değer de olgunlaşan bu iç dünyalarından kaynaklanır

Günlükler, yazarların biyografilerinde yer almayan insani zaaflarını, çaresizliklerini ve ihtiraslarını yansıtmaktadır. Günlükler, sanatçıların rol model alınabilecek üstün vasıflarını yansıttı̆̆ı gibi okuyucuyu hayal kırıklığına uğratan beşerî zaaflarını da yansıtmaktadırlar. Bu sebeple günlük okuyucusunun hayranlık duyduğu sanatçıyı öncelikle zaaflarıyla kabul etmesi gerekmektedir. Sanatçıların günlüklerinde itiraf ettikleri pişmanlıkları, yasak aşkları, korku ve kaygıları tamamıyla her insanda olabilecek zaaflardır. Günlüklerin bu yönü bilinmediği takdirde okuyucunun sanatçıya karşı olumsuz bir algısı oluşabilir. Bu sebeple günlük okuyucularının rol model aldıkları yazarları sanatçı kimliklerinin dışında insani zaaflarıyla kabul etmeleri gerekmektedir. Çünkü günlükler kişinin bir dostuna içini dökmesi ve bir dostuyla dertleşmesidir.

Günlüklerdeki yansıtıcı düşüncelerin farklı bir yönü de okurların hayatlarına ışık tutacak bilgiler içermeleridir. Günlüklerin bu bağlamda değerlendirilmeleri okuyucuların kişisel gelişimine katkı sağlayacaktır.

\section{KAYNAKLAR}

Akalın, H. Ş. (Ed.) (2011). Türkçe Sözlük, Ankara: TDK Yayınları.

Akbal, O. (1961). Günlüklerim. Deneme Özel Saylsl, Türk Dili Dil ve Edebiyat Dergisi, X(118), 788-789.

Akbal, O. (1983). Yeryüzü Korkusu, İstanbul: Yazko Yayıncılık.

Akbal, O. (2004). Anılarda Görmek. İstanbul: Alkım Yayınevi.

Akarsu, B. (2016). Felsefe Terimleri Sözlüğü, İstanbul: İnk1lâp Yayınları.

Altınova, B. (2003). Kavram Karmaşası Çerçevesinde Edebî Bir Tür Olarak Hatıra, Türkbilig, 6. 3-12.

Andaç, F. (2011). Güncenin Taşıdı̆̆ Zaman, Mustafa Şerif Onaran ve İbrahim Çelik (Ed.), Nurullah Ataç (ss.229-231), Ankara: Kültür ve Turizm Bakanlığı Yayınları.

Aruç, Y. N. (2007). İbn Rüşd’ ün Felsefi Düşüncesi, İstanbul: Rağbet Yayınları.

Atabaş, H. (2011). Günce'lerdeki Nurullah Ataç, Mustafa Şerif Onaran ve İbrahim Çelik (Ed.), Nurullah Ataç (ss.423-460), Ankara: Kültür ve Turizm Bakanlı̆̆ Yayınları.

Ataç, N. (1998a). Günce II 1953-1955, İstanbul: Can Yayınları.

Ataç, N. (1998b). Günce II 1956-1957, İstanbul: Can Yayınları.

Aydoğan, A. (2012). Düşüncenin Çağrlsı Kant-Schopenhauer-Heidegger. İstanbul: Say Yayınları.

Bakioğlu, A. ve Dalgıç, G. (2014). Eğitimcilerde Yansitıcı Düşünme, İstanbul: Bahçeşehir Üniversitesi Yayınları.

Başar, H. (2013). Nasıl Düşünelim? Ankara: Pegem Akademi Yayıncılık.

Birsel, S. (1978). Bir Edebiyat Türü Olarak Günlük. Ruznameler, Günlük Yazarlarımız ve Batıdaki Örnekleri, Milliyet Sanat Dergisi. 297. 3-9. 
Bourneur, R. and Quellet, R. (1989). Roman Dünyası ve Incelemesi, Hüseyin Gümüş (Çev.), Ankara: Kültür Bakanlığ̀ Yayınları.

Dewey, J. (1933). How We Think: A Restatement of the Relation of Reflective Thinking to the Educative Process. Boston: D. C. Heath and Company lication.

Emre, İ. (2014). Edebiyat Bilimi Teoriler, Yöntemler, Uygulamalar C.1. Ankara: Anı Yayınc1lık.

Esen, N. (2012). Günlüklerdeki Tanpınar. Ahmet Hamdi Tanpınar -Tanpınar Zamanı Son Bakışlar (s. 100106), İstanbul: Kap1 Yayınları.

Ergen, G. (2014). Öğretimde Yeni Yönelimler ve Düşünme Becerileri, Çavuş Şahin ve Salih Zeki Genç (Ed.), Öğretim Illke ve Yöntemleri (247-290), İstanbul: Paradigma Akademi.

Gökberk, M. (1993). Felsefe Tarihi, İstanbul: Remzi Kitabevi.

Günay, M. (2010). Felsefe Tarihinde Insan Sorunu, Adana: Karahan Yayınları.

Güneş, F. (2012), Öğrencilerin Düşünme Becerilerini Geliştirme, Türklük Bilimi Araştırmalarl, 32. 127-146.

Hegel, G. W. F. (2011). Tarihte Akıl, (Çev.) Önay Sözer, İstanbul: Kabalcı Yayınları.

Heimsoeth, H. (2014). Kant'in Felsefesi, (Çev.) Takiyyettin Mengüşoğlu, Ankara: Doğubatı Yayınları.

Koç, M. (2014). Ahmet Hamdi Tanpınar ve Oğuz Atay’ın Günlükleri Üzerine Karşılaştırmalı Bir Okuma Denemesi. Marmara Türkiyat Araştırmaları Dergisi 1.(1), 161-177.

Kurnaz, A. (2013). Eleştirel Düşünme Öğretimi Etkinlikleri, Konya: Eğitim Kitapevi.

Lee H. J. (2005). Understanding and Assessing Preservice Teachers Reflective Thinking, Teaching and Teacher Education, 21 (1), 699-715.

Meriç, C. (2014). Jurnal I Yayına Mahmut Ali Meriç (Haz.), İstanbul: İletişim Yayınları.

Meriç, C. (1998). Jurnal II Yayına Mahmut Ali Meriç (Haz.), İstanbul: İletişim Yayınları.

Mert, N. (2015) Günlük ve Mahrem, Hece Günlük Özel Sayısı, 222-223-224. 26-34.

Platon, (1942). Menon, (Çev.) Adnan Cemgil, Ankara: Maarif Basımevi.

Sarıcaoğlu, F. (2008). İslam Ansiklopedisi. (C.35, ss. 278-281) İstanbul: Türk Diyanet Vakfı Yayınları.

Osterman, K.F. and Kottkamp, R.B. (1993). Reflective Practice For Educators: Improving Schooling Through Professional Development, Newbury Park, CA: Corwin Press.

Özdemir, E. (1990). Örnekli Açıklamalı Edebiyat Bilimleri Sözlüğü, İstanbul: Remzi Kitapevi.

Özden, H. Ö. (1996). İbn-i Sina/Descartes Metafizik Bir Karşılaştırma, İstanbul: Dergâh Yayınları.

Tanpınar, A. H. (2018). Günlüklerin Işı̆̆̆ında Tanpınar'la Başbaşa, Zeynep Kermen ve İnci Enginün (Haz.) İstanbul: Dergâh Yayınları

Ünver, G. (2003). Yansıtıcı Düşünme, Ankara: Pegem Yayıncılık.

Yetkin, S. K. (1962), Günlük Üzerine, Türk Dili Günlük Özel Sayısı, XI (127) 432-433.

Yıldırım, T. (2011). Ömer Seyfettin Balkan Harbi Hatıralarl, İstanbul: Dün Bugün Yarın Yayınları.

\section{Elektronik Kaynak}

RTL 1 : https://sozluk.gov.tr Erişim tarihi: 20.06.2020 


\section{EXTENDED SUMMARY}

\section{Purpose}

In this study, reflective thoughts in the diaries are determined. The aim of the study is to reveal the relationship of reflective thoughts with the inner worlds and life experiences of the authors. Reflective thoughts identified in the diaries will provide an opportunity to get to know the authors from different aspects.

\section{Methodology}

In this study, reflective thoughts in the diaries are determined. The aim of the study is to reveal the relationship of reflective thoughts with the inner worlds and life experiences of the authors. Reflective thoughts identified in the diaries will provide an opportunity to get to know the authors from different aspects.

A limited number of works have been written in Turkish literature. This study examines the diaries of Nurullah Ataç, Ahmet Hamdi Tanpınar, Cemil Meriç and Oktay Akbal, who are known for their critic aspects. Therefore, the universe sampling model is used in the research. In the study where qualitative research method is applied, reflective thoughts are determined by document analysis technique. The findings determined as a result of the research are evaluated in relation to the biographies of the authors.

\section{Findings}

The basic philosophy of reflective thinking is to question one's past and reach correct information with experience. In the diaries examined within the scope of the research, it is seen that the authors frequently question their past lives and express their regrets because they could not evaluate the opportunities they received. The feeling of regret is more evident especially in the diaries of Ahmet Hamdi Tanpınar.

Nurullah Ataç, one of the first names that come to mind when it comes to the type of diary in Turkish literature, is in the regret of not keeping a diary in childhood in her diary written on January 1, 1953. He says in his diary: "Will it start after this age? I wish I would have liked to have a diary since childhood and at least my youth. I would find myself on his pages " (1998a: 11). He clearly states that he was influenced by Monsieur Guinea in his paperclip diaries. He argues in his diary that wannabe is not a deficiency for an artist.

Reflective thoughts in the diaries of Oktay Akbal are generally related to the adventure of life. The author admits his regrets when he reaches his fifties in his diary: "It was necessary to grow fifty years old to raise fears, aggravate responsibilities, escape from life..." (1983: 135).

Blind psychology is the main theme of Meriç's diaries. There are many moments when he sees useless and disreputable. But he tries to get rid of the mood of the body with reflective thoughts. He does not use this shortcoming for self-pity and interest.

Cemil Meriç also questions his responsibilities to his family in his diaries. Meriç, who devotes much of his time to reading and research, thinks that he has neglected his children for many years. He describes his relationship with his children as follows: "Will I not be able to inherit my children other than my hesitations, resignations, and feelings? Marx says it right, first of all his governess needs training" (2014. 207).

\section{Conclusion and Discussion}

In the diaries examined within the scope of the research, it was found that the authors question themselves frequently and express their regrets. As the authors self-criticize, they get the right information and make new decisions about their lives. In the diaries, the writers have reflective thoughts about their private lives and their understanding of art for years.

The common theme of the diaries examined is regrets and confessions. According to the common result of the research, regrets and confessions mature the writers' inner world. The psychological depth and aesthetic value in the writers' works are also related to these internal worlds that have matured significantly.

The diaries reflect the human weaknesses, despair, and ambitions that are not included in the 
biographies of the authors. The diaries reflect the artists' superior qualities that can be taken as role models, as well as the human weaknesses that disappoint the reader. For this reason, the artist, whose daily reader admires, must first accept the human weaknesses.

Thinking is a human ability. Man makes comparison, separation and unification with thinking ability; comprehend links and formats. Thinking in philosophy is an independent and unique act of mind. In this aspect, sensation differs from design and impression. If thinking turns to real objects, concrete thought; abstract thought becomes real if it turns to ideal objects

Systematic application of thinking types improves individuals' ability to realize knowledge, to solve problems and to generate ideas. Reflective thinking is one of the most effective methods of thinking among these species. 